
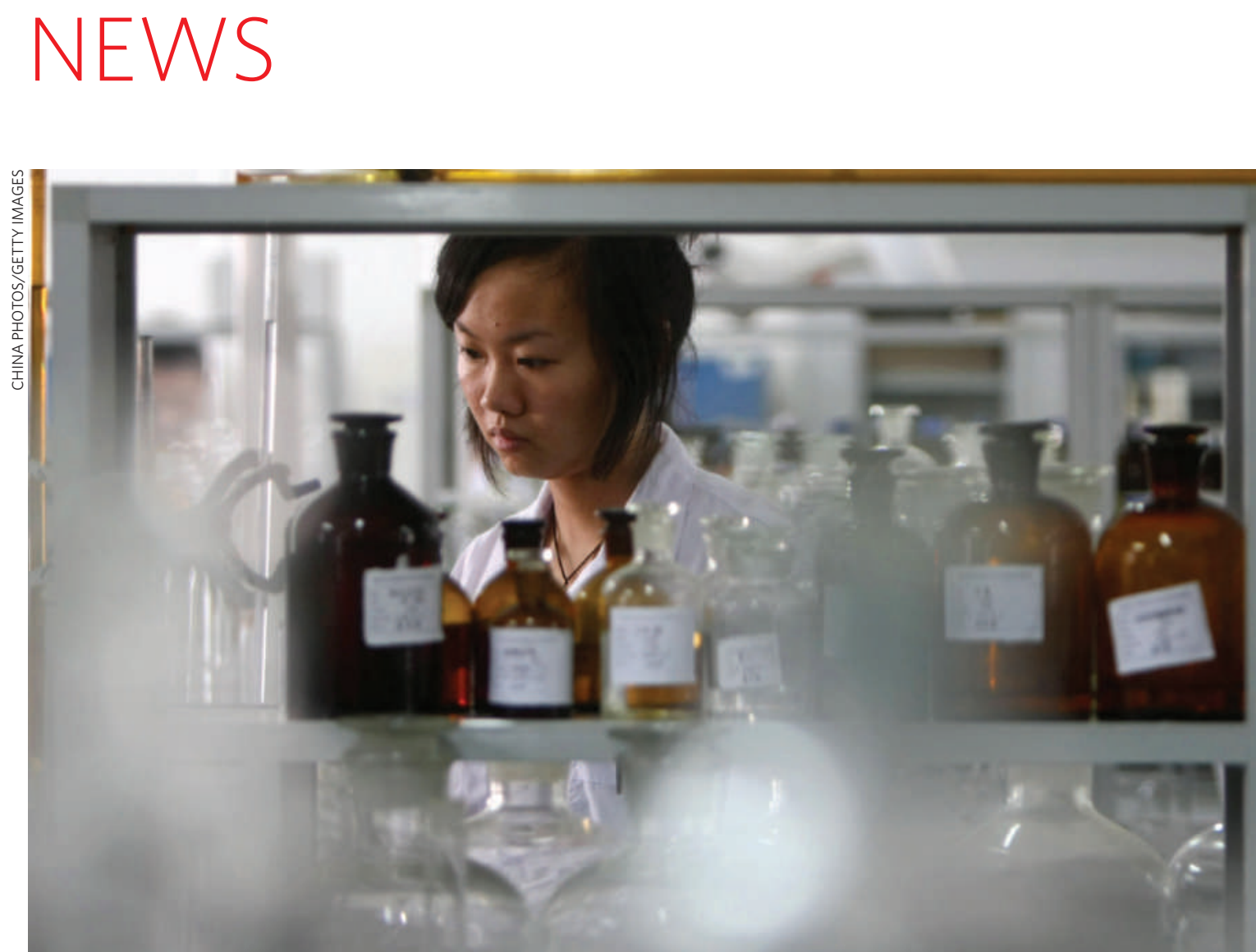

\title{
Slow shipping hobbles Chinese science
}

\section{A lack of laboratory reagents is taking its toll on researchers.}

\section{SHANGHAI}

Earlier this year, a researcher in Shanghai requested antibodies from a collaborator at Harvard University. Working with customs and shippers to arrange the transfer, including extra dry ice to keep the materials cool, cost US\$1,500 and took well over a month. "It was very tedious and very expensive," says the scientist, who did not want to be identified.

Yet this experience is speedy for China, where reagents, biological materials and other laboratory materials can take weeks or months longer to obtain than in Europe or the United States. With few local suppliers, researchers in China rely on deliveries from overseas. But the shipments regularly get hung up in customs and in a network of distributors, and product quality is sometimes compromised by the tortuous route.

The reagents problem could crimp China's ambitious plans to become one of the top five biotechnology powers by 2020 . The Chinese can build a five-star hotel, a highway or a research institute before they can get a mouse from Boston to Beijing. "If a researcher from the United States and I have the same idea at the same time, I won't even try," says Duanqing Pei, director of the Guangzhou Institute of Biomedicine and Health. "I'd never be able to keep up."

Chinese scientists like to say that a 10-million renminbi (US\$1.5-million) grant in China will go as far as a \$10-million grant in the United States, because labour and overheads are cheaper. But reagents remain some of the biggest expenses - and hassles.

This year's Beijing Olympics made a tough situation even worse. Because of tightened security restrictions, the China branches of Sigma Aldrich, one of the world's biggest suppliers of laboratory reagents, stopped importing from US plants between early August and mid-September. As a result, its China sector was the only one that failed to meet target goals for the company for the third quarter of 2008. Employees at Stealth Peptides International had to drive for two days to bring peptides from its Shanghai headquarters to a contract laboratory in Shenzen, says chief executive Dajun Yang. In Beijing, neuroscientist Minmin Luo of the National Institute of Biological Sciences couldn't get oxygen in compressed tanks, or the radioactive probes to do Southern blots. "It was very bizarre," he says.

Now things are mostly back to normal that is, normal for China. Researchers share stories of waiting a year for a shipment of basic materials. Yuqiang Ding of the Institute of Neuroscience in Shanghai says that part of the problem is that distributors pile up orders and send them all together to reduce shipment fees. Animals, cell lines or reagents with bovine serum are particularly slow to arrive because of strict regulations and confusion at customs. Knockout mice take six months to arrive from most places, says Luo. Shipping from the United States is often a little faster - about five months - because the greater number of orders has made the paperwork more routine.

The delays mean that interesting leads turned up during experiments frequently have to wait. "Sometimes you just can't plan ahead," says Luo. He often ends up saving the exciting parts of the experiment for later and doing controls - experiments that might not even be needed if the more critical parts don't turn out - until he can get what he needs. 
Some researchers have to make substitutions using less-than-ideal alternatives. Luo has applied several times for the right to obtain ketamine from Beijing manufacturers, to no avail. The drug, which can be used recreationally, is tightly controlled in China. Instead he uses phenobarbiturate, which is more difficult to dose than ketamine. "We end up killing some mice," he says. "The experiments go much slower."

Multinational pharmaceutical companies and contract research organizations, which have poured hundreds of millions of dollars into research units in China over the past few years (see Nature 455, 1168 $1170 ; 2008$ ), are not immune to the shortages. Sometimes they innovate around the problem. In one instance, Shanghai-based researchers at GlaxoSmithKline took just a week to express and purify more than 10 milligrams of a protein for assay. It would have cost more than $\$ 200,000$ and taken at least a month if ordered from a US vendor, says Jingwu Zang, head of the research centre.

But that only works for some reagents. GlaxoSmithKline wants to use its influence and size to sort out the rest. The company intends to increase its staff in China from 200 to 1,000 over the next decade and is pushing local vendors to stock reagents nearby, and others to expedite shipping. It has paid off: some shipments are down to seven days from the United States and one day within China. Zang says he also plans to collaborate with other pharmaceutical companies, many of which are now represented in Shanghai, to establish a centralized local stock facility for all users.

In Guangzhou, Anlong Xu, the vice-president for research at Sun Yat-Sen University, is working to build expertise at the custom houses and exchange agencies that must test and approve imported reagents. "They often don't know how to test the materials, and so they leave them overnight", by which time the dry ice has gone, Xu says. "We can help them." But pulling together the regulatory authorities is a headache; Xu has dedicated one assistant entirely to the task. Luo suggests a quicker alternative: a fast-track system that would accelerate shipments for accredited research institutions.

None of these innovations can arrive too soon for researchers. "Sometimes I feel so frustrated I wonder if I can still do research here," says Luo, who spent nine years in the United States. "It just goes so much faster there."

David Cyranoski

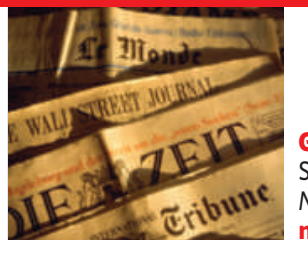

GOT A NEWS TIP?

Send any article ideas for Nature's News section to newstips@nature.com

\section{European funding plan 'unviable'}

The credibility of the European Commission's initiative to promote research collaborations between academia and industry is under threat because universities cannot afford to take part.

The Commission is setting up six public-private partnerships - known as Joint Technology Initiatives, or JTIs - that will undertake applied research under the European Union's $€ 50$-billion (US\$63 billion) Seventh Framework Programme (FP7), which runs until 2013. Roughly half of the money for the JTIs comes from European Union funds, with $€ 3.17$ billion paid by member states as part of their contribution to FP7. Industry matches the contribution in kind by offering researchers, lab space and equipment.

But some of Europe's top universities say the terms of the JTIs make it too costly for them to take part. One of the main concerns is that universities can claim only $20 \%$ of the indirect costs of these research projects including infrastructure, computing support and administrative services - from any of the JTI grants. By contrast, other FP7 projects reimburse universities with up to $60 \%$ of their indirect costs.

The University of Oxford, UK, has expressed an interest in five projects in the Innovative Medicines Initiative (IMI), which aims to speed up the drugdevelopment process and will receive $€ 1$ billion in public funds between now and 2017. But Linda Polik, European adviser at Oxford's research services unit, says the university may have to pull out because it cannot afford to take part. “Even

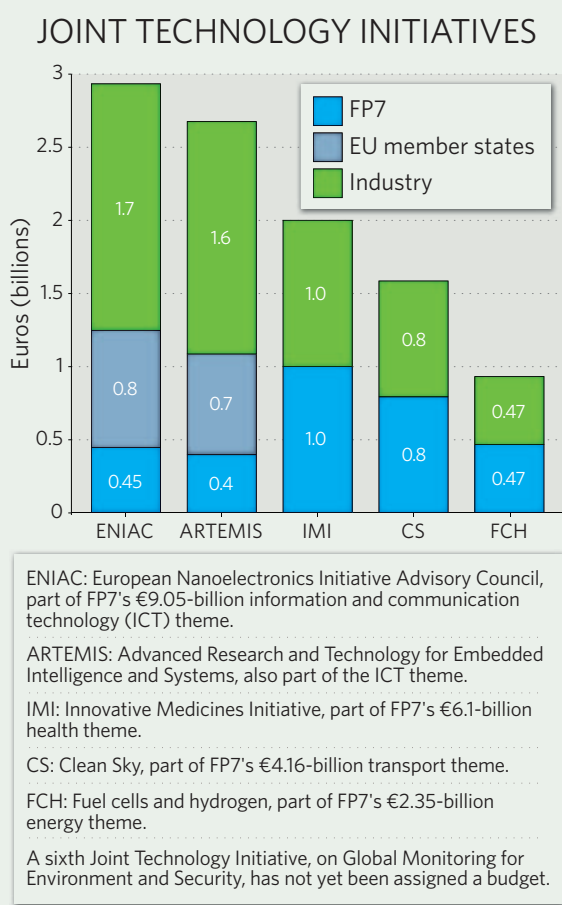

before the economic downturn we were not in a position to subsidize research to this extent. It is not financially viable to participate in the IMI."

The university complained to the Commission in September, but Polik says that the reply from European research commissioner Janez Potočnik, who has personally backed the JTI scheme - failed to address their concerns.

University College London has expressed interest in only one IMI research project because the conditions are so unfavourable, says Michael Browne, the university's head of European research and development. "I am not going to be shouting from the rooftops to get our researchers involved in these," he says, adding that the schemes "will definitely fail without university participation".

Herbert Müther, vice-dean for research at the University of Tübingen in Germany, adds that the JTIs have failed to overcome the difficulties of getting universities to collaborate with industry, such as the different styles of conducting and communicating research, and disagreements over intellectual property rights.

The European Association of Research and Technology Organisations (EARTO), which represents public and private research bodies, warns that universities and smaller businesses could "turn their backs on JTIs - as many of them did during the first IMI call for proposals if the conditions offered are not realistic".

Many research-policy experts contacted by Nature expressed the view that the JTIs are being used to subsidize industry, giving them substantial control over the intellectual property generated by the research. The Commission and industry partners involved in the IMI have agreed to set up a working group early next year to discuss the universities' concerns about these rules.

A spokesman for the European Federation of Pharmaceutical Industries and Associations in Brussels - which has five member companies on the IMI's governing board - says it is pleased with how the IMI is progressing, as it proves that industry and academic institutions can work together. The Commission says the decision to place a $20 \%$ cap on overhead costs is "a clear decision to focus as much of the funds as possible on research".

"The idea is to get research results to be applied quickly, which requires different rules to those adopted in the rest of FP7," a spokesman says. He adds that the Commission was "satisfied" with levels of interest in the IMI's first call for proposals, which saw 138 submissions. "That strikes me as quite underwhelming," says Christopher Hull, secretary general of EARTO. Natasha Gilbert

d

